\title{
Strategic Financial Performance Evaluation of the Turkish Companies Traded on ISE
}

\author{
iMKB'de Işlem Gören Türk Şirketlerinin Stratejik Finansal Performans Değerlendirmesi
}

\author{
Ali BAYRAKDAROĞLU', Neşe YALÇIN²
}

\begin{abstract}
Strategic financial performance evaluation has been more important in a highly competitive environment. The main aim of this study is to evaluate the Turkish industrial companies traded on Istanbul Stock Exchange 30 (ISE-30) with respect to seven strategic financial performance measures by using Fuzzy Analytic Hierarchy Process (FAHP) and VIKOR (VI sekriterijumsko KOmpromisno Rangiranje) method which are known as Multi Criteria Decision Making (MCDM) methods. The strategic performance measures used for performance evaluation are mostly known as the value-based financial performance measures. These seven performance measures are as follows; Economic Value Added (EVA), Refined Economic Value Added (REVA), Equity Economic Value Added (E-EVA), True Value Added (TVA), Market Value Added (MVA), Cash Flow Return on Investment (CFROI) and Cash Value Added (CVA), respectively. In this study, the weights of the performance measures are obtained by using FAHP. The companies are ranked with respect to their strategic financial performance measures' values for each year for the period 1998-2011, and also ranked with respect to the average values of these measures for the related period by using the VIKOR method.
\end{abstract}

Keywords: Strategic performance measures, performance evaluation, MCDM, FAHP, VIKOR, ISE-30

\section{INTRODUCTION}

It has been seen many changes regarding how businesses have been conducted in the growing global economy in the last decade. In order to compete in the market and maintain the supports of customers and stakeholders, companies have implemented strategic initiatives to guide, measure, and maintain exceptional performance (Smith, 2006). In the financial sector, especially in recent years; measuring the financial performance of companies has become more important. Because value-based measures have become a common tool for evaluation of corporate strategies, projects and strategic decisions from the perspective of shareholder value maximization (Oxelhelm and Wihlborg, 2002). The underlying

\section{ÖZET}

Son yıllarda işletmelerin stratejik finansal performanslarının değerlendirilmesi özellikle rekabetçi ekonomik çevrelerde önemli hale gelmiştir. Bu çalışmanın temel amacı; iMKB-30 endeksinde işlem gören imalat sanayi işletmelerinin yedi stratejik finansal performans ölçütüne göre çok kriterli karar verme (ÇKKV) teknikleri olarak bilinen Bulanık Analitik Hiyerarşi Prosesi (BAHP) ve VIKOR (VI_sekriterijumsko KOmpromisno Rangiranje) yöntemi ile değerlendirilmesidir. Iş̧letmelerin değerlendirilmesinde ele alınan bu yedi finansal ölçüt, en yaygın değer temelli finansal performans ölçütleri olarak bilinmektedir. Çalışmada ele alınan yedi ölçüt şunlardır; Ekonomik Katma Değer (EVA), Arındırıımış Ekonomik Katma Değer (REVA), Gerçek Katma Değer (E-EVA), Piyasa Katma Değeri (MVA), Yatırımın Nakit Akım Karlılığı (CFROI) ve Nakit Katma Değer (CVA). Çalışmada performans ölçütlerinin ağırlıkları BAHP ile belirlenmiştir. İşletmeler stratejik finansal performans ölçütlerinin hem 1998-2011 dönemindeki her bir yılına ait değerleri ve hem de ölçütlerin bu dönemi kapsayan ortalama değerleri bakımından VIKOR yöntemi ile sıralanmıştır.

Anahtar Kelimeler: Stratejik performans ölçütleri, performans değerlendirmesi, ÇKKV, BAHP, VIKOR, IMKB-30

cause of this situation is the increase of priorities of shareholders' expectations. For those reasons, classical measurement methods (accounting-based measures) generally depend on corporate performance has lost their validity. Instead of the classical methods, value-based measurement methods based on shareholders' expectations have been developed. So, firms have become focused more on value creation. In this environment, new mechanisms for measuring value have been developed, which do not depend too heavily on market movements and do not require a lot of estimations.

In the literature, some of the studies on the value-based performance measures are given here. The first empirical study analysis regarding the asso-

\footnotetext{
' Assist. Prof., Muğla University, Faculty of Economics and Administrative Sciences, Department of Business Administration, abayrakdaroglu@mu.edu.tr

${ }^{2}$ Assist. Prof., Nevşehir University, Faculty of Economics and Administrative Sciences, Department of Business Administration, nyalcin@nevsehir.edu.tr
} 
ciation between EVA and MVA was proposed by Stewart (1991). Lehn and Makhija (1996) used MVA as a signal for strategic change in their studies. Yook and McCabe (2001) investigated the effectiveness of MVA as an investment tool by examining its relationships with other commonly used measures. EVA and MVA are recommended by some researchers as measures for the development of companies' strategies. Boston Consulting Group and HOLT value associates suggested that CFROI is a useful strategic measure of the return that a firm earns on its invested capital (Makelainen, 1998). Damadoran (1998) compared the EVA and CFROI performance measures. Eventually, it has been suggested that this two performance measures are different from accounting measures. Obrycki and Resendes (2000) investigated the link between EVA and CFROI. Another measure is CVA which is a very similar to EVA concept. Hejazi and Oskouei (2007) suggested that both CVA and Price/ Earnings ratios had an explanatory power for each other. Three new performance measures, EVA, CFROI and CVA are analysed and evaluated to examine any association of them to stock returns by Clinton and Chen (1998).

Performance evaluation is regarded as a MCDM problem, which selects an option from a set of alternatives characterized in terms of their attributes. Several studies on performance evaluation focus on ranking of the units according to their performance measures included in their comparison environments. Feng and Wang (2000) constructed a performance evaluation process for airlines with some financial ratios. They used the grey relation analysis to select the representative indicators and used the TOPSIS method for outranking Taiwan's five major airlines. Yurdakul and İç (2003) used the TOPSIS method for the financial performance evaluation of the companies that operates in the Turkish automotive industry. Wang (2008) applied a fuzzy MCDM method to evaluate financial performance of the domestic airlines in Taiwan. And then, he utilized grey relation analysis to cluster financial ratios and found representative indicators. Yalçın Seçme, Bayrakdaroğlu and Kahraman (2009) proposed a fuzzy performance evaluation model with both financial and non-financial performance indicators for the commercial banks in the Turkish Banking Sector by using FAHP and TOPSIS methods together. Ertuğrul and Karakaşoğlu (2009) developed a fuzzy model to evaluate the financial performance of Turkish cement firms by using FAHP and TOPSIS methods together. Yalcin, Bayrakdaroglu and Kahraman (2012) have proposed a new financial performance evaluation approach to rank the firms of each sector in the Turkish manufacturing industry by using MCDM methods. In their proposed approach, both accounting-based financial performance measures (traditional financial ratios) and value-based financial performance measures are used for financial performance evaluation model.

In this study, Turkish industrial companies in ISE30 are evaluated with respect to seven strategic financial performance measures by using FAHP and VIKOR method together. For this purpose, firstly we introduced the measures used in the performance evaluation. Secondly, data set and fuzzy sets and systems are explained shortly. In addition, the VIKOR method is given in the following part). Then, the empirical study and results obtained from the analyses are given. At the last section, the conclusion of the study and also suggestions for further research are given.

\section{STRATEGIC FINANCIAL PERFORMANCE MEASURES}

In this study, seven strategic financial performance measures are used to rank the companies traded on ISE-30. These performance measures are briefly explained in the following.

The concept of EVA is a measure of economic profit and was popularized and originally trade marked by Stern Stewart Consulting Company in the 1980's. Stewart (1991) defines EVA as the difference between the net operating profit before interest, but after tax and a capital charge based on the weighted average cost of capital (WACC) multiplied by the invested capital. And also, EVA is described as after tax operating profits less the cost of the capital employed to produce those profits (Lehn and Makhija 1997). EVA can be expressed in more general terms as follows (Kramer and Pushner, 1997 and Stewart, 1991); EVA = NOPAT- cost of capital. NOPAT; Net Operating Profits after Taxes. This is Operating Profits less taxes but before financing costs. NOPAT is the residual income and it is generated from the capital invested. Cost of Capital; this is the charge for using capital. It includes a charge for the equity capital based on a cash equivalent equity multiply cost of equity rate.

REVA is an extension of the EVA methodology, providing an analytical framework for evaluating company performance in the context of shareholder value creation. REVA are both slightly modified versions of basic EVA. Bacidore et al. (1997) developed REVA by arguing that assessing the capital charge on 
the market value of the firm rather than on the economic book value of its assets. REVA is described with the consideration of the market value of the firm in the beginning of period instead of book value. EVA is also estimated as: NOPAT - (WACC - IC), where IC (Invested Capital) represents the total economic book value of the firm's assets. Bacidore et al. (1997) argued that estimating IC as the economic book value of assets is not desirable because the capital charge for the firm is based on its market-based WACC, not book-based. Namely, REVA considers the market-value of a firm. Accordingly, it is proposed to estimate EVA by using the market value of the firm's assets instead. They called this new type of EVA, as REVA; NOPATMarket Value $x$ Cost of Capital. This study examines REVA as one of main strategic performance measures for firms. REVA considers the market-value (strategy is incorporated) of a firm (Lee and Kim, 2009). Damodaran (2002) suggests that using E-EVA criteria instead of EVA as a strategic financial performance criteria. E-EVA, equity and cost of equity items having been adjusted in a different way from the traditional EVA. E-EVA can be estimated as follows (Ercan vd., 2006); $\mathrm{E}-\mathrm{EVA}=$ NOPLAT- Cost of Equity. NOPLAT; Net Operating Profit Less Adjusted Taxes. This is Operating Profits less adjusted taxes before financing costs. Cost of Equity; this is the charge for use of equity. It includes a charge for the invested adjusted equity multiply cost of equity rate.

Popularized by Stern Stewart and companies during the 1980s, EVA is widely accepted as a strategic measure of corporate performance. And also, EVA is being increasingly used both as a valuation and incentive tool. EVA is however often criticized as a wrong measure of company performance. It is often argued that the market forms expectations on the market value of the company and not on the book value of the company. Besides, the expectations formed by the market consist of both periodic cash flow and capital gains. EVA does not seem to capture the effect of either of these components of expected return. And finally, it is argued that EVA is an accounting based performance measure and hence does not accurately capture the exact performance of the companies. However, Mohanty (2003) suggested True Value Added. TVA can be calculated as; TVA = Free Cash Flow + Capital Gains - (Market Value x (1 + WACC)). He has suggested that more accurate performance' values are given by TVA measure.

MVA is also one other strategic performance measure. MVA derived from the EVA performance measure is a present value of all projected EVAs of a company in the future. And at the same time, MVA presents the extent to which a company has added value to its capital, funded from shareholders and lenders (Milunovich and Tsuie, 1996). Evans (1999) defines MVA as the difference between the capital that has been invested and the market value of the capital. MVA is the assessment within the market on what the net present value is for all investments made by the company. MVA is expressed as fallows; MVA = Market Value - Capital. Thus, the market value of a firm is the sum total of MVA and capital employed during the period (Akalu and Turner, 2002).

CFROI is the product of Boston Consulting Group (BCG) and Holt Value Associates. From the traditional return on investment, a link is created to the cash flow of a company (Madden, 1998). It is the long term internal rate of return known almost as common IRR. CFROI is determined by converting profitability data into gross cash flow and using real gross assets as an implied investment. The CFROI calculation requires four major inputs: the life of the assets, the amount of total assets, and the periodic cash flows assumed over the life of those assets and the release of nondepreciating assets in the final period of the life of the assets (Madden, 1999; Young and O. Byrne, 2001). This calculation form is called multi-period approach. The other calculation way is single-period approach. CFROI can be converted to a simpler single-period ratio. With this approach, we calculate CFROI as follows (Young \& O'Byrne, 2001); CFROI = (Gross Cash Flow - Economic Depreciation) / Gross Investment. Economic depreciation is the annual investment that must be made and gives the company's opportunity cost of funds in order to accumulate a sum equal to the original cost of the depreciable assets at the end of the asset's life. In this sense, assuming an assets life of $t$ years, economic depreciation is computed as follows: [WACC/(1+WACC)t-1]xDepreciating Assets (Martin \& Petty, 2000).

The CFROI is clearly the major measure used by BCG when measuring firm performance and valuing a company. However, BCG has also developed as a measure of economic profit and called CVA. BCG's claim is an improvement over EVA because CVA is based on cash flows, not earnings. Namely, CVA is very similar to EVA except that it includes only cash items (Martin and Petty, 2000). CVA is measured differently in two ways; direct calculation and indirect calculation that are given respectively. $C V A=$ (Gross Cash Flow-Economic Depreciation)-Capital Charge and CVA $=$ (CFROI-Cost of Capital) $\times$ Gross Investment (Hejazi and Oskouei, 2007). 


\section{DATA SET AND METHODOLOGY}

For the purpose of the study, analysis have been made upon 17 companies of which performance measures can be calculated and data are suitable among 18 industrial companies traded on ISE-30. These industrial companies with their IMKB codes are as follows: Arçelik A.Ş. (ARCLK), Doğan Şirketler Grubu Holding A.Ş. (DOHOL), Doğan Yayın Holding A.Ş. (DYHOL), Ereğli Demir ve Çelik Fabrikaları T.A.Ş. (EREGL), Hürriyet Gazetecilik ve Matbaacılık A.Ş. (HURGZ), Koç Holding A.Ş. (KCHOL), Migros Ticaret A.Ş. (MIGRS), Petkim Petrokimya Holding A.Ş. (PETKM), OMV Petrol Ofisi A.Ş. (PTOFS), H.Ö. Sabancı Holding A.Ş. (SAHOL), Türkiye Şişe ve Cam Fabrikaları A.Ş. (SISE), Tofaş Türk Otomobil Fabrikası A.Ş. (TOASO), Turkcell İletişim Hizmetleri A.Ş. (TCELL), TüpraşTürkiye Petrol Rafinerileri A.Ş. (TUPRS), Türk Hava Yolları A.O. (THYAO), Ülker Bisküvi Sanayi A.Ş. (ULKER) and Vestel Elektronik Sanayi ve Ticaret A.Ş. (VESTL). In this research process, it has been used of financial statements for 12 months of these companies which have passed from independent auditing and released to public for the period 1998-2011. These financial statements have been acquired from official web site of ISE. The performance measure' values of these companies are calculated by using released financial statements for the related period.

The aim of the MCDM is to obtain the optimum choice that has the highest degree of satisfaction for all of the relevant attributes (Yang, Chen \& Hung, 2007). In the analyses, FAHP known to be as the MCDM method is used for determining the weights of the strategic performance measures. Since exact data is inadequate for modelling real-life situations and also human judgments and preferences are often ambiguous and cannot be estimated with exact numerical values under many conditions, FAHP, a fuzzy extension of AHP, is used for obtaining the criteria weights. The fuzzy set theory first introduced by Zadeh (1965) is appropriate for dealing with uncertainty and imprecision associated with information. This theory is a valuable tool to provide measuring the ambiguity of concepts that are associated with human beings' subjective judgments that are often vague. One of the easier ways to clarify these subjective judgments is using linguistic variables. The concept of a linguistic variable is very useful in dealing with situations, which are too complex or not well defined to be reasonably described in conventional quantitative expressions (Zimmermann, 1991). In this study, the weights of the financial performance measures are obtained by using Chang's
$(1992,1996)$ extent FAHP method that is because of the its computational easiness and efficiency. In the FAHP analysis, triangular fuzzy numbers are preferred for representing the linguistic variables because of their calculation easiness and features. A fuzzy number is a special fuzzy set $A=\left\{x \in R \mid \mu_{A}(x)\right\}$, where $\mathrm{x}$ takes its values on the real line $\mathfrak{R}^{1}:-\infty<x<+\infty$ and $\mu_{A}(x)$ is a continuous mapping from $\mathfrak{R}^{1}$ to the closed interval $[0,1]$. A triangular fuzzy number can be donated as $\tilde{M}=(l, m, u)$ and its membership function $\mu_{\tilde{M}}(x): \mathfrak{R}^{1} \rightarrow[0,1]$ can be given as;

$$
\mu_{\tilde{A}}(x)=\left\{\begin{array}{cc}
0, & x<l \text { or } x>u \\
(x-l) /(m-l), & l \leq x \leq m \\
(x-u) /(m-u), & m \leq x \leq u
\end{array}\right.
$$

where $l \leq m \leq u$ and $\mathrm{l}, \mathrm{m}$, and $\mathrm{u}$ describe the smallest possible value, the most promising value, and the largest possible value of a fuzzy event, respectively. To evaluate the importance of the strategic performance measures, it is assumed that the expert group (decision makers) utilize the linguistic weigh-

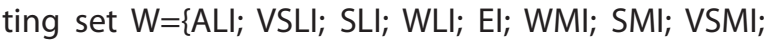
$A M I\}$, where ALI: absolutely less important, VSLI: very strongly less important, SLI: strongly less important, WLI: weakly less important, El: equally important, WMI: weakly more important, SMI: strongly more important, VSMI: very strongly more important, AMI: absolutely more important.

VIKOR method known to be as a compromise ranking method introduces an applicable technique to implement within the MCDM approaches (Opricovic, 1998). This method is based on an aggregating function representing closeness to the reference point(s). In this study, VIKOR is used to rank the industrial companies in the ISE-30 considering the seven strategic financial performance measures for the period 1998-2011. This method introduces different forms of aggregating function (Lp-metric) for ranking. The VIKOR method introduces $Q_{j}$ as a function of $L_{1}$ and $L_{\infty}$ and uses linear normalization to eliminate the units of criterion functions. In this method, the various $\mathrm{J}$ alternatives are denoted as $a_{1}, a_{2}, \ldots, a_{J}$. For an alternative $a_{j}$, the multiple attribute merit for compromise ranking was developed from the Lpmetric used in the compromise programming method (Zeleny, 1982).

$$
\begin{array}{r}
L_{p, j}=\left\{\sum_{i=1}^{n}\left[w_{i}\left(f_{i}^{*}-f_{i j}\right) /\left(f_{i}^{*}-f_{i}^{-}\right)\right]^{p}\right\}^{1 / p} \\
, \quad 1 \leq p \leq \infty ; \quad j=1,2, \ldots, J
\end{array}
$$

$L_{1, i}$ (as $\mathrm{S}_{\mathrm{j}}$ in $\mathrm{E}_{\mathrm{q}}$.(4)) and $L_{\infty, i}$ (as $\mathrm{R}_{\mathrm{j}}$ in $\mathrm{E}_{\mathrm{q}}$. (5)) are used to formulate the ranking measures. The solution obtained by $\min _{j} S_{j}$ is with a maximum group utility 
("majority" rule), and the solution obtained by minjRj is with a minimum individual regret of the "opponent". The main steps of the VIKOR method are described as follows:

Step 1: Determine the best $f_{i}^{*}$ and the worst $f_{i}^{-}$ values of all criterion functions assuming that ith function represents a benefit:

$$
f_{i}^{*}=\max _{j} f_{i j} \quad f_{i}^{-}=\min _{j} f_{i j}(3)
$$

Step 2: Compute the values $\mathrm{S}_{\mathrm{j}}$ and $\mathrm{R}_{\mathrm{j}} ; j=1,2, \ldots, J$, by the relations

$$
\begin{aligned}
& S_{j}=\sum_{i=1}^{n} w_{i}\left(f_{i}^{*}-f_{i j}\right) /\left(f_{i}^{*}-f_{i}^{-}\right)(4) \\
& R_{j}=\max _{j}\left[w_{i}\left(f_{i}^{*}-f_{i j}\right) /\left(f_{i}^{*}-f_{i}^{-}\right)\right](5)
\end{aligned}
$$

where $w_{i}$ are the weights of criteria, expressing their relative importance.

Step 3: Compute the values $\mathrm{Q}_{j^{\prime}} j=1,2, \ldots, J$, by the relation

$$
Q_{j}=v\left(S_{j}-S^{*}\right) /\left(S^{-}-S^{*}\right)+(1-v)\left(R_{j}-R^{*}\right) /\left(R^{-}-R^{*}\right)(6)
$$

where, $\quad S^{*}=\min _{j} S_{j}, S^{-}=\max _{j} S_{j} \quad$ and $R^{*}=\min _{j} R_{j}, R^{-}=\max _{j} R_{j}$

$v$ is introduced as weight of the strategy of "the majority of criteria" (or "the maximum group utility") and usually $\mathrm{v}=0,5$.

Step 4: Rank the alternatives, sorting by the values $S, R$ and $Q$, in decreasing order. The results are three ranking lists.

Step 5: Propose as a compromise solution, for given criteria weights, the alternative $\left(a^{\prime}\right)$, which is the best ranked by the measure $Q$ if the following two conditions are satisfied:
C1. "Acceptable advantage": $Q\left(a^{\prime \prime}\right)-Q\left(a^{\prime}\right) \geq D Q$ , where $a^{\prime \prime}$ is the alternative with second position in the ranking list by $Q ; D Q=1 /(J-1) ; J$ is the number of alternatives.

C2. "Acceptable stability in decision making": Alternative $a^{\prime}$ must also be the best ranked by $\mathrm{S}$ or/ and R. This compromise solution is stable within a decision making process, which could be: "voting by majority rule" (when $v>0.5$ is needed), or "by consensus" $v \approx 0.5$, or "with veto" $(v<0.5)$. Here, $v$ is the weight of the decision making strategy "the majority of criteria" (or "the maximum group utility"). If one of the conditions is not satisfied, then the set of compromise solutions is proposed, which consists of: Alternatives $a^{\prime}$ and $a^{\prime \prime}$ if only the conditions C2 are not satisfied. Alternatives $a^{\prime}, a^{\prime \prime}, \ldots, a^{(k)}$ if the conditions $\mathrm{C} 1$ are not satisfied, $a^{(k)}$ is determined by the relation $Q\left(a^{(k)}\right)-Q\left(a^{\prime}\right) \approx D Q$, the positions of these alternatives are "in closeness".

\section{EMPIRICAL RESULTS}

In this section of the study, analyses are realized regarding to 17 industrial companies. Firstly by analysing summary statistics regarding to these companies, general structures of EVA, REVA, TVA, E-EVA, MVA, CFROI and CVA values have been revealed for the related companies. Later, the performance values of the companies for each measure have been interpreted and the companies are ranked with respect to both each year's value of the strategic fi-

\begin{tabular}{|c|c|c|c|c|c|c|c|}
\hline Company & EVA* $^{*}$ & REVA* & TVA $^{*}$ & E-EVA* & MVA* $^{*}$ & CFROI** $^{* *}$ & CVA $^{*}$ \\
\hline DOHOL & 112.641 & -8.139 & -215.200 & -38.596 & 33.509 & 0,213 & -63.000 \\
\hline DYHOL & -1.690 & -15.503 & -67.888 & -938.586 & 33.448 & 0,126 & -6.954 \\
\hline ULKER & -46.813 & -102.621 & -579.459 & -28.121 & 166.944 & 0,167 & -48.918 \\
\hline $\mathrm{KCHOL}$ & -97.636 & -6.764 & 2.249 & -92.993 & -268.454 & 0,044 & -127.742 \\
\hline ARCLK & -494.883 & -657.266 & -2.749 .393 & -420.792 & 71.272 & 0,133 & -468.004 \\
\hline MIGRS & -44.179 & -22.855 & -71.681 & -34.404 & -71.315 & 0,050 & -39.063 \\
\hline SAHOL & -11.923 & -13.984 & -95.649 & -15.446 & 1.200 & 0,108 & -35.102 \\
\hline TCELL & -10.468 & -35.950 & -155.077 & -6.915 & 90.242 & 0,075 & -117.129 \\
\hline THYAO & -82.716 & -36.759 & -139.313 & -64.355 & -115.198 & 0,149 & -53.428 \\
\hline EREGL & -1.604 .351 & -1.029 .600 & -3.667 .720 & -1.215 .975 & -1.376 .075 & 0,071 & -2.096 .500 \\
\hline HURGZ & -246.545 & -365.246 & -1.356 .127 & -180.960 & 227.215 & 0,166 & -157.903 \\
\hline PETKM & -570.740 & -900.931 & -2.132 .384 & -430.321 & 61.683 & 0,016 & -1.388 .174 \\
\hline PTOFS & -313.764 & -493.112 & -2.551 .807 & -355.204 & -339.017 & 0,368 & -39.879 \\
\hline TOASO & -429.477 & -463.574 & -1.557 .947 & -259.902 & 151.033 & 0,048 & -358.831 \\
\hline SISE & -190.953 & -231.703 & -861.297 & -129.071 & -22.007 & 0,178 & -149.688 \\
\hline TUPRS & -404.065 & -955.462 & -4.260 .771 & -428.414 & 1.127 .958 & 0,118 & -972.924 \\
\hline VESTL & 13.233 & 167.380 .442 & -538.704 & -192.105 & -597.105 & 0,282 & -76.552 \\
\hline Average & -266.874 & -304.241 & -1.235 .186 & -229.089 & -48.509 & 0,136 & -364.694 \\
\hline
\end{tabular}
nancial performance measures and the average values of these measures for the period 1998-2011.

Table 1: The Average Values of the Strategic Performance Measures for Each Company For The Period 1998-2011 
Table 1 shows the average values of the strategic performance measures of the related companies for the period 1998-2011. As seen from Table 1, it can be expressed that EVA values of companies (except DOHOL and VESTL) within the context of analysis are all negative. DOHOL and VESTL have the highest positive EVA value. In spite of this, EREGL has the lowest EVA value. The average EVA value has been found as -266.874.000 TL (Turkish Liras) for the companies. The number of the companies under this value is eleven. When examining the value of REVA as a performance indicator, VESTL has the highest REVA value with a value of 167.380.442.000 TL. As to REVA value, the companies after VESTL which have the highest REVA values are $\mathrm{KCHOL}$ and $\mathrm{DOHOL}$.

When analysing EVA and REVA values all together, VESTL still has the same success. In the period analysis, the average REVA value of companies has been found as -304.241.000 TL. There have been ten companies whose value under this value in the related period. While looking at the TVA values, $\mathrm{KCHOL}$ is the only positive value (the best value), but the other companies' values are negative. As to E-EVA value, TCELL have the highest value with a value of -6.915 .000 TL. E-EVA values of companies within the context of analysis are all negative. On the other hand, the three companies TUPRS, HURGZ and ULKER have the highest MVA value, but the VESTL and EREGL have the lowest MVA value. But however, DYHOL, DOHOL and SAHOL have a positive but the lowest MVA value. As DYHOL creates the highest value in terms of CVA, PTOFS has the highest value from the point of view of CFROI. While the highest
CFROI value is $\% 36.8$, the lowest value is $\% 0.4$. The relative superiority of DYHOL is still valid from the point of CVA value. While DYHOL and SAHOL have the highest CVA value, EREGL, PETKM and TUPRS have the lowest CVA values. As a real performance measures of companies when analysing value-based measures which are strategic performance indicators in respect to whether or not they create value for shareholders, it can be seen that none of the companies can create positive value. In a word, all companies which are analysed in ISE 30 could not be successful in respect of creating shareholder value. At this point, general structure according to strategic financial performance measures of industrial companies has been produced by taking into account the averages. Generally, we can say that companies within the context of analysis are unsuccessful in terms of performance or at least they have not positive values.

Table 2 shows the average values of seven strategic financial performance measures of each year for the period 1998-2011. As seen in Table 2, while the highest performance is in the year of 1998, the lowest performance is 2003 year with respect to EVA. Similarly, relative superiority of 1998 still has the same success. In this sense, while the worst performance in REVA has experienced in 1999, the worst performance in TVA has also experienced in 2007. While the most successful year in terms of E-EVA is 1998 , for MVA is 1999. This is followed by the years 1998, 2000 and 2005. The best values observed in 1998 in terms of CFROI and CVA. CVA is not positive at any time in the related period.

Table 2: The Mean Values of Strategic Financial Performance Measures For Each Year

\begin{tabular}{|c|c|c|c|c|c|c|c|}
\hline Years & EVA & REVA & TVA & E-EVA & MVA & CFROI & CVA \\
\hline 1998 & -15.356 & -14.681 & -183.544 & -42.215 & 14.613 & 0,168 & -19.476 \\
\hline 1999 & -260.161 & -1.141 .899 & -2.057 .824 & -248.220 & 582.211 & 0,164 & -456.922 \\
\hline 2000 & -65.448 & -115.063 & -589.377 & -55.132 & 144.959 & 0,139 & -95.011 \\
\hline 2001 & -169.038 & -168.490 & -1.240 .238 & -249.803 & -3.314 & 0,137 & -548.031 \\
\hline 2002 & -463.549 & -369.573 & -1.052 .655 & -421.942 & -182.152 & 0,164 & -550.144 \\
\hline 2003 & -527.908 & -460.308 & -1.525 .427 & -352.361 & -152.040 & 0,128 & -733.420 \\
\hline 2004 & -197.105 & -155.030 & -1.605 .731 & 158.073 & -180.216 & 0,102 & -323.358 \\
\hline 2005 & -496.144 & -523.603 & -2.049 .130 & -421.455 & 39.128 & 0,119 & -629.233 \\
\hline 2006 & -181.020 & -80.892 & -1.735 .627 & -280.128 & -484.741 & 0,135 & -355.957 \\
\hline 2007 & -283.341 & -294.616 & -2.423 .229 & -395.895 & 20.323 & 0,118 & -470.521 \\
\hline 2008 & -237.356 & -141.788 & -223.898 & -213.993 & -233.005 & 0,140 & -90.179 \\
\hline 2009 & -227.990 & -228.616 & -758.858 & -313.445 & -28.473 & 0,125 & -320.867 \\
\hline 2010 & -302.854 & -240.706 & -589.114 & -190.161 & -135.284 & 0,126 & -245.092 \\
\hline 2011 & -308.964 & -324.102 & -1.257 .957 & -222.744 & -81.143 & 0,137 & -294.768 \\
\hline
\end{tabular}


For all each year, $S_{j}, R_{j}$ and $Q_{j}$ values are computed by selecting $v=0.5$ (consensus) and thus the compromise solutions are determined by using the VIKOR method. Table 3 is given as an example to show the ranking of the companies for the year 1998. As seen in Table 3 the best ranked company for the year 1998 is PETKM. This company is proposed as a compromise solution because the two conditions ( $\mathrm{C} 1$ and $\mathrm{C} 2$ ) are satisfied. Given these results,
PETKM has an acceptable advantage; in other words $Q_{[2]}-Q_{[1]}=0.1572 \geq D Q=0.0625$ (In Table-3, it can be observed that the ratings of PETKM and PTOFS are not very close to each other). And, it is observed that PETKM is stable within the decision-making process; in other words it is also the best ranked in $S_{j}$ and $R_{j}$. As a conclusion, the alternative PETKM is proposed as a compromise solution because the two conditions are satisfied.

Table 3: Ranking of The Companies For The Year 1998 With The VIKOR Method (For v=0.50)

\begin{tabular}{|c|c|c|c|c|c|c|}
\hline \multirow{2}{*}{ Companies } & \multicolumn{2}{|c|}{$\mathrm{S}_{\mathrm{j}}$} & \multicolumn{2}{c|}{$\mathrm{R}_{\mathrm{j}}$} & \multicolumn{2}{c|}{$\mathrm{Q}_{\mathrm{j}}$} \\
\cline { 2 - 7 } & Distance & Ranking & Distance & Ranking & Distance & Ranking \\
\hline DOHOL & 0.3945 & 9 & 0.1441 & 10 & 0.3563 & 10 \\
\hline DYHOL & 0.3638 & 4 & 0.1298 & 6 & 0.3051 & 5 \\
\hline ULKER & 0.3801 & 8 & 0.1364 & 8 & 0.3305 & 8 \\
\hline KCHOL & 0.3964 & 10 & 0.1470 & 11 & 0.3631 & 11 \\
\hline ARCLK & 0.4008 & 12 & 0.1405 & 9 & 0.3553 & 9 \\
\hline MIGRS & 0.3967 & 11 & 0.1483 & 12 & 0.3657 & 12 \\
\hline SAHOL & 0.3776 & 7 & 0.1328 & 7 & 0.3222 & 7 \\
\hline TCELL & 0.3658 & 5 & 0.1296 & 5 & 0.3065 & 6 \\
\hline THYAO & 0.4209 & 13 & 0.1661 & 13 & 0.4175 & 13 \\
\hline EREGL & 0.7257 & 17 & 0.3497 & 17 & 1.0000 & 17 \\
\hline HURGZ & 0.3367 & 3 & 0.1058 & 3 & 0.2399 & 3 \\
\hline PETKM & 0.1351 & 1 & 0.0667 & 1 & 0.0000 & 1 \\
\hline PTOFS & 0.3038 & 2 & 0.0748 & 2 & 0.1572 & 2 \\
\hline TOASO & 0.6258 & 16 & 0.2770 & 16 & 0.7869 & 16 \\
\hline SISE & 0.4381 & 14 & 0.1728 & 14 & 0.4441 & 14 \\
\hline TUPRS & 0.6055 & 15 & 0.2535 & 15 & 0.7283 & 15 \\
\hline VESTL & 0.3671 & 6 & 0.1138 & 4 & 0.2797 & 4 \\
\hline
\end{tabular}

In the following, obtained ranking results of the companies for each year from 1999 to 2011 are summarized.

For the year 1999, the best ranked company is VESTL. Given these results, VESTL does not have an acceptable advantage; in other words . On the other hand, we observe that VESTL is stable within the decision-making process; in other words it is also the best ranked in $\mathrm{S}$. Because $\mathrm{C} 1$ is not satisfied only, VESTL, TCELL, DYHOL, ULKER, SAHOL, KCHOL, MIGRS, DOHOL, HURGZ, THYAO companies are proposed as a set of compromise solution. This is the result of two inequities: $Q_{[10]}-Q_{[1]}=0.0598<D Q=0.0625$ and $Q_{[11]}-Q_{[1]}=0.0850>D Q=0.0625$.

For the year 2000, the best ranked company is TCELL. Given these results, TCELL does not have an acceptable advantage; in other words $Q_{[2]}-Q_{[1]}=0.0014 \leq D Q=0.0625$. On the other hand, we observe that TCELL is stable within the decision-making process; in other words it is also the best ranked in $\mathrm{S}$. Because $\mathrm{C} 1$ is not satisfied only, TCELL, DYHOL, ULKER, SAHOL, KCHOL, DOHOL, MIGRS, VESTL, THYAO companies are proposed as a set of compromise solution. This is the result of two inequities: $Q_{[10]}-Q_{[1]}=0.0598<D Q=0.0625$ and $Q_{[1]}-Q_{[1]}=0.0850>D Q=0.0625$.

For the year 2001, the best ranked company is VESTL. Given these results, VESTL does not have an acceptable advantage; in other words $Q_{[2]}-Q_{[1]}=0.0347 \leq D Q=0.0625$. On the other hand, we observe that VESTL is stable within the decision-making process; in other words it is also the best ranked in $\mathrm{S}$. Because $\mathrm{C} 1$ is not satisfied only, VESTL, KCHOL, TCELL, SAHOL, THYAO, DOHOL, DYHOL, ULKER, MIGRS companies are proposed as a set of compromise solution. This is the result of two inequities: $Q_{[9]}-Q_{[1]}=0.0576<D Q=0.0625$ and $Q_{[10]}-Q_{[1]}=0.0773>D Q=0.0625$.

For the year 2002, the best ranked company is DYHOL. Given these results, DYHOL does not have an acceptable advantage; in other words $Q_{[2]}-Q_{[1]}=0.0085 \leq D Q=0.0625$. On the other hand, we observe that VESTL is stable within the decision-making process; in other words it is also the best ranked in $\mathrm{S}_{\mathrm{j}}$. Because $\mathrm{C} 1$ is not satisfied only, 
DYHOL, TCELL, ULKER, KCHOL, SAHOL, DOHOL, MIGRS, THYAO, SISE companies are proposed as a set of compromise solution. This is the result of two inequities: $Q_{[9]}-Q_{[1]}=0.0419<D Q=0.0625$ and $Q_{[10]}-Q_{[1]}=0.0773>D Q=0.0625$.

For the year 2003, the best ranked company is TCELL. Given these results, TCELL does not have an acceptable advantage; in other words $Q_{[2]}-Q_{[1]}=0.0004 \leq D Q=0.0625$. On the other hand, we observe that TCELL is stable within the decision-making process; in other words it is also the best ranked in $\mathrm{R}_{\mathrm{j}}$. Because $\mathrm{C} 1$ is not satisfied only, TCELL, DYHOL, SAHOL, DOHOL, MIGRS, THYAO companies are proposed as a set of compromise solution. This is the result of two inequities: $Q_{[6]}-Q_{[1]}=0.0517<D Q=0.0625$ and $Q_{[7]}-Q_{[1]}=0.0679<D Q=0.0625$.

For the year 2004, the best ranked company is VESTL. Given these results, VESTL does not have an acceptable advantage; in other words $Q_{[2]}-Q_{[1]}=0.0337 \leq D Q=0.0625$. On the other hand, we observe that VESTL is stable within the decisionmaking process; in other words it is also the best ranked in S. Because C1 is not satisfied only, VESTL and DOHOL companies are proposed as a set of compromise solution. This is the result of one inequity: $Q_{[3]}-Q_{[1]}=0.0679>D Q=0.0625$.

For the year 2005, the best ranked company is TCELL. Given these results, TCELL does not have an acceptable advantage; in other words $Q_{[2]}-Q_{[1]}=0.0032 \leq D Q=0.0625$. On the other hand, we observe that TCELL is stable within the decision-making process; in other words it is also the best ranked in $\mathrm{Rj}$. Because $\mathrm{C} 1$ is not satisfied only, TCELL, DYHOL, SAHOL, DOHOL, MIGRS, THYAO, ULKER, SISE companies are proposed as a set of compromise solution. This is the result of two inequities: $Q_{[8]}-Q_{[1]}=0.0583<D Q=0.0625$ and $Q_{[3]}-Q_{[1]}=0.1125>D Q=0.0625$.

For the year 2006, the best ranked company is VESTL. This company is proposed as a compromise solution because the two conditions ( $\mathrm{C} 1$ and (2) are satisfied. Given these results, VESTL has an acceptable advantage; in other words $Q_{[2]}-Q_{[1]}=0.0822 \geq D Q=0.0625$ And, it is observed that VESTL is stable within the decision-making process; in other words it is also the best ranked in $S_{j}$ and $R_{j}$. As a conclusion, VESTL is proposed as a compromise solution because the two conditions are satisfied.

For the year 2007, the best ranked company is DOHOL. Given these results, DOHOL does not have an acceptable advantage; in other words $Q_{[2]}-Q_{[1]}=0.0038 \leq D Q=0.0625$. On the other hand, we observe that DOHOL is stable within the decision-making process; in other words it is also the best ranked in $\mathrm{S}_{i}$. Because $\mathrm{C} 1$ is not satisfied only, DOHOL, ULKER, SAHOL, DYHOL, TCELL, KCHOL, MIGRS, THYAO companies are proposed as a set of compromise solution. This is the result of two inequities: $\quad Q_{[8]}-Q_{[1]}=0.0391<D Q=0.0625 \quad$ and $Q_{[9]}-Q_{[1]}=0.0753>D Q=0.0625$.

For the year 2008, the best ranked company is VESTL. Given these results, VESTL does not have an acceptable advantage; in other words $Q_{[2]}-Q_{[1]}=0.0086 \leq D Q=0.0625$. On the other hand, we observe that VESTL is stable within the decision-making process; in other words it is also the best ranked in $\mathrm{Sj}$ and $\mathrm{Rj}$. Because $\mathrm{C} 1$ is not satisfied only, VESTEL, DOHOL, ULKER, SAHOL, DYHOL, TCELL, TUPRS, MIGRS companies are proposed as a set of compromise solution. This is the result of two inequities: $Q_{[8]}-Q_{[1]}=0.0568<D Q=0.0625$ and $Q_{[9]}-Q_{[1]}=0.0680>D Q=0.0625$.

For the year 2009, the best ranked company is DOHOL. Given these results, DOHOL does not have an acceptable advantage; in other words $Q_{[2]}-Q_{[1]}=0.0189 \leq D Q=0.0625$. On the other hand, we observe that $\mathrm{DOHOL}$ is not stable within the decision-making process; in other words it is not the best ranked in $\mathrm{S}_{j}$ or/and $\mathrm{R}_{\mathrm{j}}$. Because both $\mathrm{C} 1$ and $\mathrm{C} 2$ are not satisfied together, it cannot be proposed a set of compromise solution.

For the year 2010, the best ranked company is DOHOL. Given these results, DOHOL does not have an acceptable advantage; in other words $Q_{[2]}-Q_{[1]}=0.0067 \leq D Q=0.0625$. On the other hand, we observe that DOHOL is stable within the decision-making process; in other words it is also the best ranked in $\mathrm{S}$. Because $\mathrm{C} 1$ is not satisfied only, DOHOL, ULKER, DYHOL, SAHOL, TCELL, TUPRS, MIGRS, KCHOL, THYAO companies are proposed as a set of compromise solution. This is the result of two inequities: $Q_{[9]}-Q_{[1]}=0.0434<D Q=0.0625$ and $Q_{[10]}-Q_{[1]}=0.0671>D Q=0.0625$.

For the year 2011, the best ranked company is DOHOL. Given these results, DOHOL does not have an acceptable advantage; in other words $Q_{[2]}-Q_{[1]}=0.0038 \leq D Q=0.0625$. On the other hand, we observe that $\mathrm{DOHOL}$ is stable within the decision-making process; in other words it is also the best ranked in $\mathrm{S}$. Because $\mathrm{C} 1$ is not satisfied only, DOHOL, ULKER, SAHOL, TCELL, DYHOL, KCHOL, MIGRS, 
THYAO companies are proposed as a set of compromise solution. This is the result of two inequities: $\quad Q_{[8]}-Q_{[1]}=0.0391<D Q=0.0625 \quad$ and $Q_{[9]}-Q_{[1]}=0.0753>D Q=0.0625$.
In the end, obtained ranking result of the companies with respect to the average values of the strategic performance measures for the years 1998-2011 is given in Table 4.

Table 4: Ranking of The Companies For The Average Values of The Year 1998-2011

\begin{tabular}{|c|c|c|c|c|c|c|}
\hline \multirow{2}{*}{ Companies } & \multicolumn{2}{|c|}{$\mathrm{S}_{\mathrm{i}}$} & \multicolumn{2}{c|}{$\mathrm{R}_{\mathrm{i}}$} & \multicolumn{2}{c|}{$\mathrm{Q}_{\mathrm{i}}$} \\
\cline { 2 - 7 } & Distance & Ranking & Distance & Ranking & Distance & Ranking \\
\hline DOHOL & 0.1138 & 2 & 0.0562 & 2 & 0.0062 & 3 \\
\hline DYHOL & 0.1115 & 1 & 0.0562 & 3 & 0.0049 & 1 \\
\hline ULKER & 0.1489 & 8 & 0.0572 & 4 & 0.0281 & 6 \\
\hline KCHOL & 0.1572 & 9 & 0.0717 & 8 & 0.0573 & 8 \\
\hline ARCLK & 0.4744 & 14 & 0.1747 & 14 & 0.4137 & 14 \\
\hline MIGRS & 0.1347 & 6 & 0.0616 & 6 & 0.0273 & 5 \\
\hline SAHOL & 0.1183 & 3 & 0.0579 & 5 & 0.0116 & 4 \\
\hline TCELL & 0.1205 & 4 & 0.0533 & 1 & 0.0052 & 2 \\
\hline THYAO & 0.1487 & 7 & 0.0638 & 7 & 0.0392 & 7 \\
\hline EREGL & 0.9799 & 17 & 0.3497 & 17 & 1.0000 & 17 \\
\hline HURGZ & 0.2833 & 11 & 0.1128 & 11 & 0.1993 & 11 \\
\hline PETKM & 0.5319 & 16 & 0.2263 & 15 & 0.5338 & 15 \\
\hline PTOFS & 0.3976 & 13 & 0.1399 & 13 & 0.3108 & 13 \\
\hline TOASO & 0.3673 & 12 & 0.1336 & 12 & 0.2828 & 12 \\
\hline SISE & 0.2353 & 10 & 0.0845 & 9 & 0.1240 & 10 \\
\hline TUPRS & 0.5103 & 15 & 0.2378 & 16 & 0.5409 & 16 \\
\hline VESTL & 0.1281 & 5 & 0.0886 & 10 & 0.0691 & 9 \\
\hline
\end{tabular}

As seen in Table 4, the best ranked company is DYHOL. Given these results, DYHOL does not have an acceptable advantage; in other words $Q_{[2]}-Q_{[1]}=0.0020>D Q=0.0625$. On the other hand, we observe that DYHOL is stable within the decision-making process; in other words it is also the best ranked in $\mathrm{Sj}$. Because $\mathrm{C} 1$ is not satisfied only, DYHOL, TCELL, DOHOL, SAHOL, MIGRS, ULKER, THYAO, KCHOL companies are proposed as a set of compromise solution. This is the result of two inequities: $Q_{[7]}-Q_{[1]}=0.0413<D Q=0.0625$ and $Q_{[8]}-Q_{[1]}=0.745>D Q=0.0625$.

\section{CONCLUSION}

Globalizing economy, competitive conditions and changes in the economy have brought out new approaches and methods searching in terms of evaluating performance of companies. At this point, value-based management concept has been started to adopt and value-based performance measures are developed in order companies to display an efficient risk-capital management and provide a systematic cash flow. In this study, seven strategic financial performance measures are used to evaluate the performance of the companies for the period 1998 to 2011 with the VIKOR method. In this method, the weights of the measures are obtained by using FAHP. In the related time period of the study, the best ranked company and the compromise solutions are given according to the $\mathrm{v}=0.5$ (consensus) for both each year and overall years. In addition to the measures used in this study, other strategic financial performance measures such as net value added (NAV), Wealth Added Index (WAI), Shareholder Value Added (SVA) etc. and also strategic non-financial performance measures can be taken into account in future studies. Furthermore, alternative MCDM methods such as ELECTRE; PROMETHEE and ORESTE etc. can be used for performance evaluation in further studies. 


\section{REFERENCES}

Akalu, M.M. ve Turner, J.R. (2002) "Adding Shareholder Value Through Project Performance Measurement, Monitoring \& Control: A Critical Review" Erasmus Research Institute of Management Research Paper Series, No:38.

Bacidore, J.M., Boquist, J.A., Milbourn, T.T. ve Thakor, A.V. (1997) "The Search for the Best Financial Performance Measure" Financial Analysts, 11-20.

Chang, D.Y. (1996) "Applications of the Extent Analysis Method on Fuzzy AHP” European Journal of Operational Research, 95(3):649-655.

Chang, D.Y. (1992) "Extent Analysis and Synthetic Decision" Optimization Techniques and Applications, 1:352.

Clinton, B.D. ve Chen, S. (1998) "Do New Performance Measures Measure Up?” Management Accounting, 80:38- 43.

Damodaran, A. (1998) "Value Creation and Enhancement: Back to the Future" Contemporary Finance Digest, 2:5-52.

Damodaran, A, (2002) Investment Valuation: Tools and Techniques for Determining The Value of Any Assets, New York, John Wiley \& Sons Inc.

Ercan, M,K., Öztürk, M.B., Başc1, E.S. ve Demirgüneş, K. (2006) Firma Değerlemesi: Banka Uygulaması, İstanbul, Literatür Yayınları.

Ertuğrul, İ. ve Karakaşoğlu, N. (2009) "Performance Evaluation of Turkish Cement Firms with Fuzzy Analytic Hierarchy Process and TOPSIS Methods" Expert Systems with Applications, 36:702-715.

Evans, M.H. (1999) "Creating Value Through Financial Management" http://www.exinfm.com, (07.07.2011)

Feng, C.M. ve Wang, R.T. (2000) "Performance Evaluation for Airlines Including the Consideration of Financial Ratios" Journal of Air Transport Management, 6:133-142.

Hejazi, R. ve Oskouei, M.M. (2007) "The Information Content of Cash Value Added (CVA) and P/E Ratio: Evidence on Association with Stock Returns for Industrial Companies in the Tehran Stock Exchange" Iranian Accounting \& Auditing Review, 14:21-36.

Kramer, J.K. ve Pushner, J.R. (2001) "An Inter Industry Analysis of Economic Value Added as a Proxy for market Value Added" Journal of Applied Finance, 11:41-49.
Lee, S. ve Kim, W.G. (2009) "EVA, Refined EVA, MVA, or Traditional Performance Measures for the Hospitality Industry?" International Journal of Hospitality Management, 28:439-44.

Lehn, K. ve Makhija, A.K. (1997) "EVA, Accounting Profits and CEO Turnover" Journal of Applied Corporate Finance, 10:90-97.

Lehn, K. ve Makhija, A.K. (1996) "EVA and MVA: As Performance Measures and Signal for Strategic Change" Strategy and Leadership, 24:34-39.

Madden B.J. (1999) CFROI Valuation:Cash Flow Return On Investment, A Total System Approach to Valuing The Firm, Great Britain, Butterworth-Heinemann Finance.

Makelainen, E. (1999) "Economic Value Added as a Management Tool” Helsinki School of Economics and Business Administration Working Paper.

Martin, J.D. ve Petty, J.W. (2000) Value Based Management: The Corporate Response to the Shareholder Revolution, Boston, Harvard Business School Press.

Milunovich, S. ve Tsuie, A. (1996) "EVA in the Computer Industry" Journal of Applied Corporate Finance, 9:104-115.

Mohanty, P. (2003) "In Defense EVA" Social Science Research Network Working Paper Series.

Opricovic, S. (1998), "Multi-Criteria Optimization of Civil Engineering Systems" Faculty of Civil Engineering Working Paper.

Oxelheim, L. ve Wihlborg, C.(2002) "Recognizing Macroeconomic Fluctuations in Value Based Management" The Research Institute of Industrial Economics Working Paper.

Smith, J.M. (2006) "Using A Balanced Scorecard as A Strategic Tool in Public Purchasing" Second International Public Procurement Conference Proceedings, 21-23 September, Italy.

Stewart, G.B. (1980) "EVA: Fact \& Fantasy" Journal of Applied Corporate Finance, 7:72-84.

Stewart, G.B., (1991) The Quest for Value, New York , Harper Business.

Wang, Y.J.(2008) "Applying FMCDM to Evaluate Financial Performance of Domestic Airlines in Taiwan" Expert Systems with Applications, 34:1837-1845. 
Yalçın S.N., Bayrakdaroğlu, A. ve Kahraman, C. (2009) "Fuzzy Performance Evaluation in Turkish Banking Sector using Analytic Hierarchy Process and TOPSIS” Expert Systems with Applications, 36:1169911709.

Yalcin, N., Bayrakdaroglu, A. ve Kahraman, C. (2012) "Application of Fuzzy Multi-Criteria Decision Making Methods for Financial Performance Evaluation of Turkish Manufacturing Industries" Expert Systems with Applications, 39:350-364.

Yang, T., Chen, M. ve Hung, C. (2007) "Multiple Attribute Decision-Making Methods for the Dynamic Operator Allocation Problem" Mathematics and Computers in Simulation, 73:285-299.

Yook, K.C. ve McCabe, G.M. (2001) "MVA and the Cross-Section of Expected Stock Returns" The Journal of Portfolio Management, 27:75-87.
Young D.S. and O.Byrne S.F. (2001) EVA and ValueBased Management A Practical Guide to Implementation, USA, Mc Graw-Hill.

Yurdakul, M. ve İç, Y.T. (2003) "An illustrative Study Aimed to Measure and Rank Performance of Turkish Automotive Companies Using TOPSIS" Journal of The Faculty of Engineering and Architecture of Gazi University, 18:1-18

Zadeh, L.A. (1965) "Fuzzy Sets" Information Control, 8:338-353.

Zimmermann, H.J. (1991) Fuzzy Set Theory and Its Applications, 2nd Edition, London, Kluwer Academic Publishers. 